\title{
KEMAMPUAN KONEKSI MATEMATIS DAN BERPIKIR KRITIS SISWA DALAM PEMBELAJARAN MATEMATIKA MELALUI MODEL BRAIN-BASED LEARNING
}

\author{
Firmanila Kurnia Ulfa ${ }^{1}$ \\ ${ }^{1}$ Program Studi Pendidikan Matematika, Universitas Negeri Semarang \\ Email: 1firmanilaulfa@students.unnes.ac.id
}

\begin{abstract}
ABSTRAK
Di era revolusi industri 4.0 ini, kemajuan IPTEK dan tatanan dunia terjadi secara global, disruptif, dan sangat kompetitif. Untuk menghadapi hal itu, perlu disiapkan generasi yang memiliki kemampuan berpikir tingkat tinggi sebagai alat untuk bertindak dan mengambil keputusan yang tepat dalam berbagai situasi di masa depan. Matematika sebagai salah satu mata pelajaran wajib di sekolah dinilai memegang peran penting dalam meningkatkan kemampuan siswa untuk bepikir kritis, sistematis, logis, kreatif, dan berkolaborasi secara efektif. Sikap dan cara berpikir seperti ini dapat dikembangkan melalui pembelajaran matematika, karena matematika merupakan ilmu yang memiliki struktur dan keterkaitan yang kuat dan jelas antarkonsepnya sehingga memungkinkan siapapun yang mempelajarinya terampil dalam berpikir secara rasional. Oleh karena itu, mengembangkan kemampuan koneksi matematis dan berpikir kritis-matematis dalam pembelajaran matematika sangatlah penting. Metode brain-based learning (BbL) adalah salah satu model pembelajaran yang menawarkan suatu konsep pembelajaran yang diselaraskan dengan cara kerja otak dan didesain secara alamiah untuk belajar, sehingga dapat diterapkan untuk menstimulasi kemampuan koneksi matematis dan berpikir kritis siswa. Artikel ini memaparkan bagaimana model BbL menstimulasi kemampuan koneksi dan berpikir kritis matematis siswa dalam pembelajaran matematika yang bermuara pada peningkatan mutu pendidikan di Indonesia. Metode penulisan yang digunakan dalam artikel ini adalah studi pustaka.
\end{abstract}

Kata Kunci: kemampuan koneksi matematis, berpikir kritis-matematis, brain-based learning

\begin{abstract}
In this era of industrial revolution 4.0, advances in science and technology and world order occur globally, are disruptive, and very competitive. To deal with this, it is necessary to prepare a generation with high-level thinking skills as a tool to act and make the right decisions in various situations in the future. Mathematics as one of the compulsory subjects in schools is considered to have an important role in improving students' ability to think critically, systematically, logically, creatively, and collaborate effectively. Attitudes and ways of thinking like this can be developed through learning mathematics, because mathematics is a science that has a strong and clear structure and linkages between its concepts that allow anyone who studies it to be skilled in thinking rationally. Therefore, developing mathematical connection skills and criticalmathematical thinking in mathematics learning is very important. The brain-based learning (BbL) method is a learning model that offers a learning concept that is aligned with the workings of the brain and is designed naturally for learning, so that it can be applied to stimulate students' mathematical connection skills and critical thinking. This article describes how the BbL model stimulates students' mathematical critical thinking and connection abilities in mathematics learning which leads to improving the quality of education in Indonesia. The writing method used in this article is literature study.
\end{abstract}

Keywords: mathematical connection skills, critical-mathematical thinking, brain-based learning 


\section{PENDAHULUAN}

Untuk menghadapi tantangan di era global, perlu disiapkan generasi yang memiliki kemampuan berpikir tingkat tinggi sebagai alat untuk bertindak dan mengambil keputusan yang tepat dalam berbagai situasi di masa yang akan datang. Matematika sebagai salah satu mata pelajaran wajib di sekolah memegang peran penting dalam meningkatkan kemampuan siswa untuk berpikir kritis, sistematis, logis, kreatif, dan berkolaborasi secara efektif. Sikap dan cara berpikir seperti ini dapat dikembangkan melalui pembelajaran matematika, karena matematika merupakan ilmu yang memiliki struktur dan keterkaitan yang kuat dan jelas antarkonsepnya. Hal ini memungkinkan siapapun yang mempelajarinya terampil dalam berpikir secara rasional dan siap menghadapi permasalahan dalam kehidupan di masa yang akan datang (Setiawan, 2012).

Kemampuan koneksi matematis merupakan salah satu kemampuan berpikir tingkat tinggi yang sangat penting dan harus dikembangkan, karena dalam pembelajaran matematika setiap konsep berkaitan satu sama lain. Melalui koneksi matematis, konsep pemikiran dan wawasan siswa terhadap matematika akan semakin terbuka luas, tidak hanya terfokus pada topik yang sedang dipelajari, sehingga akan menimbulkan sikap positif terhadap matematika itu sendiri. Lestari, K. (2014:37) mengatakan bahwa jika siswa memiliki wawasan yang luas, maka siswa akan memiliki kecakapan dalam memecahkan masalah dan mengambil keputusan secara masuk akal (reasonable), mendalam (in dept), dapat dipertanggungjawabkan (responsible) dan berdasarkan pemikiran yang cerdas (skillfull thinking). Kecakapankecakapan tersebut merupakan bagian dari kemampuan berpikir kritis. Dengan demikian, penguasaan kemampuan koneksi yang baik dapat menunjang kemampuan siswa untuk dapat berpikir kritis.

Berpikir kritis adalah berpikir secara rasional dan reflektif yang memfokuskan terhadap hal yang diyakini. Rasional berarti keyakinan dan argumentasi yang berdasarkan kepada bukti, aktual, relevan dan tentunya terpercaya (Sundari, Parno, Kusairi, 2016: 405). Sedangkan reflektif artinya sikap mempertimbangkan dengan tepat, teliti dan hati-hati terhadap segala kemungkinan keputusan yang akan diambil. Kemampuan berpikir kritis merupakan bagian dari kemampuan berpikir matematis yang perlu dimiliki oleh setiap siswa dalam menghadapi berbagai permasalahan. Menurut Anderson dalam Lestari, K. (2014) ketika kemampuan berpikir kritis dikembangkan, seseorang akan cenderung untuk mencari kebenaran, berpikir divergen (terbuka dan toleran terhadap ide-ide baru), dapat menganalisis masalah dengan baik, berpikir secara sistematis, penuh rasa ingin tahu, dewasa dalam berpikir, dan dapat berpikir secara mandiri. Kecakapan inilah yang nantinya akan menjadi pintu gerbang menuju masa depan yang cemerlang.

Namun, fakta di lapangan menunjukkan bahwa kemampuan koneksi dan berpikir kritis matematis siswa belum sesuai dengan yang diharapkan. Hal ini dapat dilihat dari hasil survei TIMSS (Trends in International Mathematics and Science Study) yang dirancang untuk meneliti pengetahuan serta kemampuan matematika dan sains peserta didik bahwa kemampuan matematika peserta didik Indonesia menurut Benchmark Internasional TIMSS 2015 masih belum optimal. Indonesia hanya memperoleh nilai 397 di bawah nilai rata-rata internasional yaitu 500 dan berada pada peringkat 44 dari 49 negara (Hadi, 2019). Salah satu faktor penyebab belum optimalnya hasil TIMSS Indonesia ini adalah masih rendahnya kemampuan koneksi dan berpikir kritis siswa. Oleh karena itu, guru sebagai salah satu tokoh utama dalam pembelajaran harus mengembangkan kemampuan koneksi dan berpikir kritis matematis siswa dengan menggunakan strategi, pendekatan, metode, atau teknik yang banyak melibatkan siswa aktif dalam pembelajaran.

Menurut NCTM (2000:17) peningkatan kualitas pendidikan matematika untuk semua siswa membutuhkan pengajaran matematika yang efektif di semua ruang kelas. Pengajaran yang efektif adalah satu-satunya cara yang dapat mempersiapkan siswa untuk menghadapi 
tantangan global karena mampu mempersiapkan siswa untuk menyerap pengetahuan baru, menghubungkannya dengan pengetahuan sebelumnya dan membuat rantai pengetahuan untuk bekerja di lingkungan yang dinamis (Khan 2012:83). Mengajar matematika dengan efektif adalah upaya yang kompleks, dan tidak ada resep yang mudah untuk membantu semua siswa belajar. Anghileri dalam Anthony dan Margaret (2009:156) menyatakan bahwa guru yang efektif mampu mendukung siswa untuk membuat koneksi dengan memberi kesempatan siswa terlibat dalam tugas yang kompleks dan menetapkan tujuan bahwa mereka menjelaskan pemikiran dan strategi solusi mereka dan mereka mendengarkan pemikiran orang lain. Hal ini sejalan dengan pernyataan Ball dalam Clark dan Oyer (2014:2) bahwa "pengajaran yang baik adalah sesuatu untuk dipelajari, bukan warisan".

Selain itu, guru professional juga harus merancang pembelajaran efektif yang mampu menyeimbangkan seluruh potensi berpikir siswa sehingga akan terjadi keseimbangan kognitif pada diri siswa. Pembelajaran yang cocok dengan karakteristik tersebut adalah pembelajaran berbasis kemampuan otak atau Brain-based Learning (BbL), karena pembelajaran ini diselaraskan dengan cara kerja otak yang didesain secara alamiah untuk belajar (Jensen, 2008:5). Pembelajaran berbasis kemampuan otak ini tidak terfokus pada keterurutan, tetapi lebih mengutamakan pada kesenangan dan kecintaan siswa akan belajar, sehingga siswa dapat dengan mudah menyerap materi yang sedang dipelajari. BbL mempertimbangkan apa yang sifatnya alami bagi otak dan bagaimana otak dipengaruhi oleh lingkungan dan pengalaman (Jensen, 2008: 12).

Berdasarkan uraian di atas, penulis termotivasi untuk membahas bagaimana model $\mathrm{BbL}$ menstimulasi kemampuan koneksi dan berpikir kritis matematis siswa dalam pembelajaran matematika melalui model brain-based learning yang bermuara pada peningkatan mutu pendidikan di Indonesia.

\section{METODE}

Dalam artikel ini metode penulisan yang digunakan penulis adalah library research (studi pustaka). Teknik pengumpulan data yang penulis gunakan dalam hal ini adalah melakukan identifikasi wacana dari buku-buku, artikel, jurnal, web (internet), skripsi/tesis, ataupun informasi lainnya yang berhubungan dengan judul artikel ini. Library research merupakan metode penulisan dengan objek kajian yang bersumber pada pustaka-pustaka. Pustaka primer yang digunakan berupa jurnal ilmiah nasional/internasional, artikel ilmiah, dan skripsi/tesis. Sedangkan pustaka sekunder yang penulis gunakan adalah buku dan website yang relevan serta terkait dengan kemampuan koneksi matematis dan berpikir kritis siswa dalam pembelajaran matematika melalui model brain-based learning. Tahapan analisis penulisan artikel ini adalah penulis melakukan reduksi data (melakukan pemilihan, pemfokusan, penyederhanaan, abstraksi dan pentransformasian data mentah dalam catatancatatan tertulis), display data (data kemudian didisplay hingga memberikan pemahaman terhadap data tersebut agar bisa menentukan langkah selanjutnya), dan kesimpulan (setelah reduksi data terlaksana maka dilakukan konklusi atau penarikan kesimpulan dari data yang telah diteliti).

\section{HASIL DAN PEMBAHASAN}

\section{Kemampuan Koneksi Matematis}

Koneksi matematis (mathematical connections) merupakan salah satu kemampuan yang harus mendapat penekanan di setiap jenjang pendidikan. Kemampuan koneksi matematis terbagi dalam tiga macam yaitu koneksi antar topik matematis, koneksi dengan disiplin ilmu pengetahuan yang lain, dan koneksi dengan dunia nyata. Gagasan koneksi matematis telah lama diteliti oleh W.A. Brownell tahun 1930-an, namun pada saat itu ide koneksi matematik hanya terbatas pada koneksi aritmetik (Bergeson, 2000:37). Koneksi matematis digagas karena ilmu matematika tidaklah terpartisi dalam berbagai topik yang saling terpisah, namun matematika merupakan satu kesatuan. Selain itu matematika juga 
tidak bisa terpisah dari ilmu pengetahuan lain dan masalah-masalah yang terjadi dalam kehidupan. Tanpa koneksi matematika maka siswa harus belajar dan mengingat terlalu banyak konsep dan prosedur matematika yang saling terpisah (NCTM, 2000:275).

Kemampuan koneksi matematis merupakan hal yang penting. Namun siswa yang menguasai konsep matematika tidak dengan sendirinya pintar dalam mengoneksikan matematika. Lembke dan Reys dalam Bergeson (2000: 38) mengatakan dalam sebuah penelitian ditemukan bahwa siswa sering mampu mendaftar konsep-konsep matematika yang terkait dengan masalah riil, tetapi hanya sedikit siswa yang mampu menjelaskan mengapa konsep tersebut digunakan dalam aplikasi itu. Dengan demikian kemampuan koneksi perlu dilatihkan kepada siswa sekolah. Apabila siswa mampu mengkaitkan ide-ide matematika maka pemahaman matematikanya akan semakin dalam dan bertahan lama karena mereka mampu melihat keterkaitan antartopik dalam matematika, dengan konteks selain matematika, dan dengan pengalaman hidup sehari-hari (NCTM, 2000:64). Siswa dapat melihat bahwa koneksi matematik sangat berperan dalam topik-topik di dalam matematika, konteks yang menghubungkan matematika dan pelajaran lain, dan dalam kehidupannya. Melalui pembelajaran yang menekankan keterhubungan ide-ide dalam matematika, siswa tidak hanya belajar matematika namun juga belajar menggunakan matematika.

Dalam pembelajaran di kelas, koneksi matematis antar konsep-konsep dalam matematika sebaiknya didiskusikan oleh siswa. Hiebert dan Carpenter dalam Bergeson (2000: 37) mengungkapkan bahwa pengoneksian antar-ide matematika yang diajarkan secara eksplisit oleh guru tidak menjamin siswa dapat memahaminya secara bermakna. Kebiasaan siswa yang tidak berusaha mencari sumber materi menyebabkan siswa belum terampil menemukan konsep matematika untuk menyelesaikan permasalahan matematika (Firman \& Purnami, 2016). Mereka mengandalkan guru ceramah sehingga siswa mengalami kesulitan menyelesaikan permasalahan matematika (Munawaroh \& Kurniasih, 2016). Hal ini menunjukkan kemampuan koneksi matematis siswa masih rendah, sehingga diperlukan strategi atau pendekatan yang tepat dalam pembelajaran. Pembelajaran yang sesuai adalah yang memfasilitasi siswa aktif melakukan koneksi sendiri. Dalam hal ini siswa tidak boleh dipandang sebagai objek pembelajaran yang hanya menerima materi dari guru, namun sebaliknya siswa dianggap sebagai individu aktif yang mampu mengembangkan potensi matematikanya sendiri.

\section{Kemampuan Berpikir Kritis-Matematis}

Renstein dan Lander (1990:80) menyatakan bahwa berpikir kritis adalah proses memahami bagaimana jalannya proses berpikir dan pembelajaran, menggunakan kemampuan yang lebih tinggi untuk memahami permasalahan, menganalisis, menyintesis, dan menilai suatu ide secara logis. Untuk dapat memiliki kemampuan berpikir kritis yang baik peserta didik harus belajar mengidentifikasi persoalan, mengidentifikasi hubungan antarelemen, menyimpulkan implikasi, menduga alasan, mengombinasikan elemen bebas untuk membentuk pola pikir baru (kreatifitas), dan membuat interpretasi asli (Orlich, Harder, Callahan, dkk, 2007: 291). Kemampuan berpikir kritis sangat diperlukan sebagai upaya menghadapi berbagai masalah dan berguna untuk menemukan solusi dari masalah tersebut. Berpikir kritis menuntut interpretasi dan evaluasi terhadap observasi, komunikasi, dan sumber-sumber informasi lainnya. Kemampuan berpikir kritis yang diajarkan di sekolah menuntut kemampuan siswa dalam bernalar berdasarkan logika mereka.

Kemampuan berpikir kritis matematis adalah kemampuan berpikir dalam menyelesaikan masalah matematika yang melibatkan pengetahuan matematika, penalaran matematika dan pembuktian matematika (Piawa, 2010). Pengembangan berpikir kritis pada pelajaran matematika di dalam kelas dapat dilakukan melalui aktivitas seperti membandingkan, membuat kontradiksi, induksi, generalisasi, mengurutkan 
mengklasifikasikan, membuktikan, mengaitkan, menganalisis, mengevaluasi, dan membuat pola, dirangkaikan secara berkesinambungan (Applebaum, 2015).

Kemampuan berpikir kritis siswa dalam pembelajaran matematika masih harus terus ditingkatkan dan dibangun melalui perhatian khusus yang diberikan oleh guru. Rendahnya kemampuan berpikir kritis matematis siswa dapat dilihat melalui hasil belajar matematika siswa yang tergolong cukup dan karakteristik jawaban siswa ketika menjawab soal matematika berbentuk soal cerita dan pemecahan masalah. Oleh sebab itu, kemampuan berpikir kritis matematis perlu dibangun secara perlahan dalam proses pembelajaran matematika. Kemampuan berpikir kritis matematis siswa dapat dikembangkan melalui kegiatan berdiskusi dalam proses pembelajaran berlangsung karena berdiskusi melibatkan siswa saling membantu dan mengundang siswa lainnya untuk aktif dalam pembelajaran (Saputra, Joyoatmojo, Wardani, \& Sangka, 2019). Kemampuan berpikir kritis ini akan sangat membantu siswa dalam menghadapi berbagai tantangan di masa yang akan datang di dalam kehidupan siswa. Meskipun hasil berpikir kritis tidak secara langsung terlihat namun siswa yang memiliki berpikir kritis dapat dicirikan melalui gaya bicara dan mengatur strategi dalam menghadapi masalah di kehidupan sehari-hari.

\section{Model Pembelajaran Brain-based learning}

Brain Based Learning adalah sebuah konsep untuk menciptakan pembelajaran dengan berorientasi pada upaya pemberdayaan potensi otak siswa. Menurut Jensen (2008) terdapat tiga strategi utama yang dapat dikembangkan dalam implementasi Brain Based Learning yaitu (1) menciptakan lingkungan belajar yang menantang kemampuan berpikir siswa, (2) menciptakan lingkungan pembelajaran yang menyenangkan, (3) menciptakan situasi pembelajaran yang aktif dan bermakna bagi siswa (active learning).

Triune Theory merupakan sebuah temuan penting untuk mengembangkan strategi pembelajaran Brain-Based Learning dan memberdayakan seluruh potensi diri siswa (Abdurrahman, 2013). Kecenderungan umum yang terjadi di sekolah Indonesia adalah pembelajaran tradisional yang hanya memfungsikan otak kecil saja, dimana pembelajaran bersifat teacher centered dengan menjadikan siswa sebagai objek pembelajaran dengan aktivitas utamanya menghafal materi pelajaran, mengerjakan tugas guru, menerima hukuman jika melakukan kesalahan, dan kurang mendapatkan penghargaan terhadap hasil karyanya. Pembelajaran tradisional tersebut, jika terus dipertahankan akan membawa dampak buruk bagi siswa, kondisi ini akan memunculkan sikap kegagalan dan mempertahankan diri. Siswa akan merasa yang mereka kerjakan bukan apa yang mereka inginkan. Seorang guru sebaiknya disiapkan untuk membantu siswa dalam segala hal, dari perhatian seorang guru kepada siswa sampai peningkatan kemampuan memori (ingatan) siswa.

Strategi Brain-Based Learning membantu siswa merepresentasikan berpikir secara visual, kinestetik, dan fonetik. Teknik tersebut membutuhkan tempat dalam sebuah kotak perlengkapan, dalam hal ini, yaitu otak yang prima (pada usia yang terbaik dalam perkembangannya) untuk belajar. Tracey Tokuhama-Espinosa mempresentasikan lima kunci konsep dalam topik yang dia bawakan. Konsep ini memberikan akses kepada kita mengenai yang sedang kita bicarakan, yaitu Brain-Based Learning: (1) Otak manusia unik seperti halnya wajah, (2) Semua otak tidak sama karena konteks dan kemampuan mempengaruhi pembelajaran, (3) Otak bisa berubah karena pengalaman, (4) Otak sangat lentur, (5) Otak mengkoneksikan informasi baru dengan informasi lama (Abdurrahman, 2013).

Teori atau landasan filosofis yang mendukung model BbL, diantaranya yaitu aliran behaviorisme, aliran kognitif dan pendekatan konstruktivisme.

\section{Aliran Psikologi Tingkah Laku (Behaviorisme)}

Menurut aliran behaviorisme, belajar adalah suatu proses perubahan perilaku yang dapat diamati oleh orang lain, termasuk oleh pengajar. Didalam aliran ini, peserta didik akan dikatakan berhasil dalam belajar apabila ia sudah dapat memecahkan suatu masalah dengan 
menunjukkan perilaku secara kasat mata. Misalkan saja dengan mampu menjawab atau menyelesaikan soal-soal matematika dengan benar. Apabila perilaku manusia atau peserta didik tidak mengalami perubahan perilaku secara kasat maka pengajaran yang dilakukan belum berhasil. Tugas utama pengajar yang menganut aliran behaviourisme ini adalah menciptakan kondisi lingkungan belajar, menyediakan bahan pembelajaran, menggunakan metode dan media pembelajaran, menggunakan pujian, penguatan yang positif dan negatif, bahkan bila terpaksa memberikan hukuman yang efektif untuk membuat peserta didik berubah menjadi lebih baik (Suparman,2012).

Tokoh aliran psikologi tingkah laku, salah satunya adalah Edward L. Thorndike. Teori Thorndike (Hudoyo, 1988: 12) diantaranya mengungkapkan the law of exercise (hukum latihan) yang dasarnya menunjukkan bahwa hubungan stimulus dan respon akan semakin kuat manakala terus-menerus dilatih dan diulang, sebaliknya hubungan stimulus respon akan semakin lemah manakala tidak pernah diulang. Jadi semakin sering suatu pelajaran diulang, maka akan semakin dikuasai pelajaran itu.

\section{Aliran Kognitif dan Pendekatan Konstruktivisme}

Aliran konstruktivisme adalah bagian dari aliran kognitivisme yang memfokuskan pada pengembangan kemampuan peserta didik untuk membangun atau mengonstruksi sendiri pengetahuan baru melalui proses berpikir mensintesis pengetahuan dan pengalaman lama dan baru. Teori konstruktivistik memahami belajar sebagai proses pembentukan (konstruksi) pengetahuan oleh siswa itu sendiri. Artinya peserta didiklah yang membangun sendiri pengetahuan baru dengan melalui pengalaman-pengalamn yang didapatkannya untuk meningkatkan kemampuan koneksi matematis dan berpikir kritis bagi dirinya sendiri. Tugas guru hanya sebagai fasilitator yang membantu menyediakan sumber-sumber pembelajaran sehingga peserta didik diberikan kebebasan dalam berpikir dan menyediakan tangga pemahaman yang puncaknya adalah pemahaman siswa terhadap suatu materi dalam pembelajaran.

Beberapa tokoh aliran konstruktivisme diantaranya adalah David Ausubel dan Jean Piaget. Teori Ausubel (Ruseffendi, 1988: 172) terkenal dengan belajar bermakna dan pentingnya pengulangan sebelum belajar dimulai. Sedangkan teori Piaget (Ruseffendi, 1988: 132-133) mengungkapkan:

1. Perkembangan intelektual terjadi melalui tahap-tahap beruntun yang selalu terjadi dengan urutan yang sama.

2. Tahap-tahap itu didefinisikan sebagai kluster dari operasi-operasi mental (pengurutan, pengekalan, pengelompokan, pembuatan hipotesis, penarikan kesimpulan) yang menunjukkan adanya tingkah laku intelektual.

3. Gerak melalui tahap-tahap itu dilengkakan oleh keseimbangan yang menguraikan interaksi antara pengalaman (asimilasi) dan struktur kognitif yang timbul.

Pendekatan konstruktivisme mengungkapkan bahwa belajar matematika adalah proses pemecahan masalah. Ruseffendi (1988: 241) menyatakan bahwa pemecahan masalah itu lebih mengutamakan kepada proses daripada kepada hasilnya (output). Guru bukan hanya sebagai pemberi jawaban akhir atas pertanyaan siswa, melainkan mengarahkan mereka untuk membentuk (mengkonstruksi) pengetahuan.

\section{Kemampuan Koneksi Matematis dan Berpikir Kritis Siswa Melalui Metode Brain- Based Learning dalam Pembelajaran Matematika}

Dalam dokumen NCTM (2000), disebutkan bahwa terdapat lima kemampuan dasar matematika yang merupakan standar yakni pemecahan masalah (problem solving), penalaran dan bukti (reasoning and proof), komunikasi (communication), koneksi (connections), dan representasi (representation). Dengan mengacu pada lima standar kemampuan NCTM di atas, tujuan pembelajaran matematika menurut Kemendikbud 2013 yaitu (1) meningkatkan 
kemampuan intelektual khususnya kemampuan tingkat tinggi siswa, (2) membentuk kemampuan siswa dalam menyelesaikan masalah secara sistematik, (3) memperoleh hasil belajar yang tinggi, (4) melatih siswa dalam mengomunikasikan ide-ide, khususnya dalam menulis karya ilmiah, dan (5) mengembangkan karakteristik siswa. Dalam kedua dokumen tersebut, kemampuan koneksi matematis dan berpikir kritis merupakan kemampuan strategis yang menjadi tujuan pembelajaran matematika.

Kemampuan koneksi matematis adalah kemampuan dalam mengaitkan konsepkonsep matematika baik antar konsep matematika itu sendiri maupun mengaitkan konsep matematika dengan bidang lain. Proses penciptaan koneksi dalam pembelajaran matematika dapat dilakukan melalui $\mathrm{BbL}$, mengingat dalam pembelajaran tersebut terdapat tahap inisiasi dan akuisisi. Tahap ini merupakan tahap penciptaan koneksi pada saat neuron-neuron saling "berkomunikasi" satu sama lain (Jensen, 2008:53). Semakin terkoneksi jaringan-jaringan tersebut, maka akan semakin merangsang kemampuan berpikir siswa, yang pada akhirnya akan semakin besar pula pemaknaan yang diperoleh siswa dari pembelajaran. Tugas-tugas matematika yang bervariasi, dapat melatih siswa untuk menggunakan dan mengembangkan koneksi matematis. Ini menjadi dasar bahwa kemampuan koneksi matematis dapat ditingkatkan melalui pembelajaran matematika menggunakan $\mathrm{BbL}$.

Kemampuan selanjutnya yang perlu dikembangkan adalah berpikir kritis. Berpikir kritis adalah proses mental yang bertujuan menganalisis atau mengevaluasi informasi yang diperoleh dari hasil pengamatan, pengalaman akal sehat, atau komunikasi yang dilakukan siswa selama pembelajaran. Kemampuan berpikir kritis siswa dalam pembelajaran matematika masih harus terus ditingkatkan dan dibangun melalui perhatian khusus yang diberikan oleh guru. Rendahnya kemampuan berpikir kritis matematis siswa dapat dilihat melalui hasil belajar matematika siswa yang tergolong cukup dan karakteristik jawaban siswa ketika menjawab soal matematika berbentuk soal cerita dan pemecahan masalah. Oleh sebab itu, kemampuan berpikir kritis matematis perlu dibangun secara perlahan dalam proses pembelajaran matematika. Kemampuan berpikir kritis ini akan sangat membantu siswa dalam menghadapi berbagai tantangan di masa yang akan datang di dalam kehidupan siswa. Meskipun hasil berpikir kritis tidak secara langsung terlihat namun siswa yang memiliki berpikir kritis dapat dicirikan melalui gaya bicara dan mengatur strategi dalam menghadapi masalah di kehidupan sehari-hari.

Terdapat lima indikator dalam berpikir kritis yaitu Basic Clarification (memberikan penjelasan sederhana), (2) The Base for a decision (membangun keterampilan dasar), (3) Inference (menyimpulkan), (4) Advance Clarification (memberikan penjelasan lebih lanjut), (5) Supposition and Integrations (mengatur strategi dan taktik). Untuk mengembangkan kelima indikator berpikir kritis dalam pembelajaran matematika, guru perlu menciptakan lingkungan belajar yang menantang kemampuan berpikir siswa yang disesuaikan dengan cara otak bekerja secara alamiah untuk belajar. Hal tersebut merupakan salah satu strategi yang digunakan dalam pembelajaran BbL. Ini menjadi dasar bahwa kemampuan berpikir kritis dapat ditingkatkan melalui pembelajaran matematika menggunakan BbL.

Merujuk pada konsep konstruktivisme pendidikan, keberhasilan belajar siswa ditentukan oleh seberapa mampu mereka membangun pengetahuan dan pemahaman tentang suatu materi pelajaran berdasarkan pengalaman belajar yang mereka alami sendiri. Riset menunjukkan bahwa otak mengembangkan lima sistem pembelajaran primer yaitu emosional, sosial, kognitif, fisik dan reflektif. Jika guru memahami bagaimana sistem pembelajaran primer (emosional, sosial, kognitif, fisik, reflektif) berfungsi, maka mengajar akan lebih efektif dan tidak membosankan. Sistem pembelajaran kognitif memang sangat berkaitan langsung dalam pembelajaran matematika, walupun begitu bukan berarti aspek kognitif saja yang harus dikembangkan dalam pembelajaran matematika, hal ini dikarenakan aspek 
kognitif tidak akan berkembang dengan optimal jika dalam pembelajaran tidak melibatkan komponen otak yang lain.

Brain-Based Learning adalah pembelajaran yang mengoptimalkan kemampuan otak secara keseluruhan. Di dalam model Brain-Based Learning terdapat tujuh tahapan dasar pembelajaran yang dapat mengembangkan kemampuan berpikir kritis dan kreatif siswa. Tahap-tahap Pembelajaran Brain-Based Learning (Jensen, 2008: 484):

\section{a. Tahap Pra-Pemaparan}

Fase ini memberikan ulasan pada otak tentang pembelajaran baru. Pra-pemaparan membantu otak membangun peta konseptual yang lebih baik.

$>$ Beritahukan pada siswa materi yang akan dipelajari selanjutnya / buatlah mind mapping dan tempelkan pada papan tulis. Tujuan dari informasi ini adalah agar siswa mencari informasi tentang materi tersebut sebelum pembelajaran berlangsung. Semakin banyak informasi/ latar belakang yang mereka miliki semakin banyak koneksi yang dapat mereka buat.

Temukanlah ketertarikan dan latar belakang siswa, mulailah dari tempat dimana siswa berada pada dasar pengetahuan mereka.

$>$ Gunakan sarana pendukung/media belajar yang penuh dengan warna. Contohnya pada materi kubus dan balok, buatlah jaring-jaring dan model bentuk kubus dan balok dengan warna-warna yang menarik.

$>$ Doronglah nutrisi otak yang baik, jika proses pembelajaran berlangsung lebih dari 45 menit, pastikan siswa mendapat air minum yang cukup.

$>$ Rencanakanlah strategi "membangun" otak, misalnya melakukan relaksasi atau peregangan setiap jam.

\section{b. Tahap Persiapan}

Otak dapat belajar paling baik dari pengalaman konkret terlebih dahulu. Pada tahap ini, guru menyampaikan tujuan pembelajaran dan penjelasan awal tentang materi yang akan dipelajari dan mengaitkannya dalam kehidupan sehari-hari.

\section{c. Tahap Inisiasi dan Akusisi}

Tahap ini merupakan tahap penciptaan koneksi atau pada saat neuron-neuron berhubungan. Sumber untuk akusisi ini bisa meliputi diskusi, pengalaman praktis, proyek-proyek kelompok, dan lain-lain. Pada tahap ini siswa diberi permasalahan. Biarkan siswa merasa kewalahan sementara dengan memberikan soal-soal yang menantang, hal ini akan diikuti dengan antisipasi, keingintahuan, dan pencarian untuk menemukan makna bagi dirinya-sendiri sehingga akan memacu proses berpikir kritis dan kreatif siswa.

\section{d. Tahap Elaborasi}

Tahap ini memastikan siswa tidak hanya sekadar mengulang informasi dari faktafakta yang ada secara mekanik, tetapi juga membangun jalur neural yang kompleks dalam otak mereka sehingga dapat menghubungkan subjek-subjek menjadi bermakna. Pada tahap ini siswa dilatih untuk mengembangkan kemampuan berpikir kritis dan kreatifnya karena elaborasi memberikan kesempatan pada otak kita untuk menyortir, menyelidiki, menganalisis, menguji dan memperdalam pembelajaran.

Biarkan siswa mengeksplorasi permasalahan yang diberikan melalui sumber-sumber belajar seperti buku, jurnal, internet, dan lain-lain.

Setelah kegiatan berdiskusi, koordinasikan siswa untuk mempresentasikan hasil diskusi kelompok, sedangkan peserta didik yang lain memperhatikan, memberikan komentar dan pendapat, atau memberikan pertanyaan. Dari presentasi ini, diharapkan peserta didik dapat mengembangkan pertanyaan-pertanyaan dan menemukan jawaban yang tepat dari permasalahan yang diberikan. 


\section{e. Tahap Inkubasi dan Memasukkan Memori}

Tahap ini menekankan pentingnya waktu untuk istirahat dan waktu untuk mengulang kembali. Otak belajar efektif dari waktu ke waktu, bukan langsung dalam satu waktu.

> Sediakan waktu untuk perenungan tanpa bimbingan/waktu istirahat.

- Biarkan siswa melakukan peregangan /relaksasi.

Sediakan waktu dan tempat bagi siswa untuk mendengarkan musik.

\section{f. Tahap Verifikasi}

Tahap ini penting untuk siswa dan guru. Pembelajaran paling baik diingat oleh siswa ketika mereka memiliki model atau metafora yang berkaitan dengan konsep/materi yang telah dipelajari. Pada tahap ini biarkan siswa membuat mind-mapping/model/metafora tentang materi yang telah dipelajari sesuai dengan kreativitas mereka.

> Berikan soal-soal materi pelajaran yang memfasilitasi kemampuan berpikir siswa dari mulai tahap pengetahuan (knowledge) sampai tahap evaluasi menurut tahapan berpikir berdasarkan taxonomy bloom.

$>$ Siswa membuat tulisan tentang apa yang sudah mereka pelajari (misalnya artikel, rangkuman, essay, dan lain-lain).

\section{g. Tahap Perayaan dan Integrasi}

Dalam tahap ini sangat penting untuk melibatkan emosi. Buatlah perayaan kecil seperti bersorak atau tepuk tangan sebelum menutup pelajaran.

\section{SIMPULAN DAN SARAN}

Kemampuan koneksi matematis dan berpikir kritis adalah kemampuan yang sangat penting untuk dikembangkan dalam pembelajaran matematika. Melalui koneksi matematis, konsep pemikiran dan wawasan siswa terhadap matematika akan semakin terbuka luas tidak hanya terfokus pada topik yang sedang dipelajari, sehingga akan menimbulkan sikap positif terhadap matematika itu sendiri. Penguasaan kemampuan koneksi yang baik dapat menunjang kemampuan siswa untuk dapat berpikir kritis. Siswa yang memiliki kemampuan baik dalam berpikir kritis akan mampu menyelesaikan berbagai masalah dan tantangan yang akan terjadi di masa depan. Untuk menstimulasi kemampuan koneksi matematis dan berpikir kritis diperlukan suatu pendekatan atau strategi yang tepat dalam pembelajaran matematika. Brain based learning (Bbl) adalah salah satu model pembelajaran yang tepat untuk menstimulasi dua kemampuan tersebut. Bbl menawarkan suatu konsep untuk menciptakan pembelajaran yang berorientasi pada upaya pemberdayaan otak siswa. Upaya pemberdayaan otak tersebut dilakukan melalui tiga strategi berikut: (1) menciptakan lingkungan belajar yang menantang kemampuan berpikir siswa; (2) menciptakan lingkungan pembelajaran yang menyenangkan; (3) menciptakan situasi pembelajaran yang aktif dan bermakna bagi siswa.

Dari hasil studi literatur yang telah kami lakukan, metode Brain Based Learning (BbL) sangat cocok digunakan dalam pembelajaran matematika di sekolah untuk menstimulasi kemampuan koneksi matematis dan berpikir kritis siswa dalam menyelesaikan masalah-masalah tingkat tinggi. Metode BbL ini mengarahkan siswa untuk melatih koneksi matematis dan terus berupaya untuk memiliki ketrampilan berpikir kritis/tingkat tinggi dalam menyelesaikan setiap persoalan. Guru sebagai salah satu tokoh utama dalam pembelajaran dapat mempelajari teori $\mathrm{BbL}$ dan kemudian mengimplementasikannya pada pembelajaran matematika di sekolah. Dengan begitu tujuan pendidikan matematika untuk mencetak generasi yang mampu berpikir kritis, kreatif, logis, sistematis, dan berkolaborasi secara aktif dapat tercapai. Dengan bekal ketrampilan tersebut generasi Indonesia akan mampu hidup dan bersaing di era revolusi industri 4.0 yang sangat dinamis dan disruptif ini.

\section{DAFTAR RUJUKAN}

Abdurrahman, Ginanjar \& Mukti Sintawati. (2013). Strategi Brain Based Learning dalam Pembelajaran Matematika Untuk Mengembangkan Kemampuan Berpikir Kritis dan Kreatif Siswa. Seminar Nasional Matematika dan Aplikasinya. 
Anthony, Glenda. \& Margaret Walshaw. (2009). Characteristics of Effective Teaching of Mathematics: A View from The West. 2(2), 147-164.

Applebaum, M. (2015). Activating pre-service mathematics teachers ' critical thinking. European Journal of Science and Mathematics Education, 3(1), 77-89. Retrieved from https://files.eric.ed.gov/fulltext/EJ1107804.pdf

Bergeson, T. (2000). Teaching and Learning Mathematics: Using Research to Shift From the "Yesterday" Mind to the "Tommorow" Mind. [Online]. Tersedia: www.k12.wa.us.

Clark, Tom \& Elizabeth Oyer. (2014). Stimulating Mathematical Thinking. White Paper. Carmel, IN: EvalSolutions Inc.

Firman, \& Purnami, A. S. (2016). Upaya Meningkatkan Keaktifan dan Hasil Belajar Matematika Melalui Pendekatan Open Ended Siswa Kelas X SMA Taman Madya Jetis. UNION: Jurnal Pendidikan Matematika, 4(2), 231-238. Retrieved from http://jurnal.ustjogja.ac.id/index.php/union/article/view/438

Hadi, S. (2019). TIMSS INDONESIA ( TRENDS IN INTERNATIONAL MATHEMATICS AND SCIENCE STUDY ). 562-569.

Hudojo, Herman, (1988), Mengajar Belajar Matematika, Depdikbud, Dirjen Dikti, P2LPTK, Jakarta.

Jensen, Eric. (2008). Brain Based Learning Pembelajaran Berbasis Kemampuan Otak. Celeban Timur: Pusataka Pelajar.

Khan, Shahinshah Babar. (2012). Preparation Of Effective Teachers Of Mathematics for effective Teaching Of Mathematics. Journal Of Education And Instructional Studies In The World, 2(4), 82-88.

Lestari, Karunia Eka. (2014). Implementasi Brain-Based learning Untuk Meningkatkan Kemampuan Koneksi dan kemampuan Berpikir Kritis serta Motivasi Belajar Siswa SMP. Jurnal Pendidikan UNSIKA. ISSN 2338-2996.

Munawaroh, A., \& Kurniasih, N. (2016). Peningkatan Berpikir Kritis Matematika Melalui Model Kooperatif Tipe Talking Chips Setting Snowball Throwing. EKUIVALENPendidikan Matematika, 19(1), 12-17. Retrieved from http://ejournal.umpwr.ac.id/index.php/ekuivalen/article/view/2753/0

NCTM. (2000). Principles and Standards for School Mathematics. Tersedia di www.nctm.org.

Orlich, D. C., Harder, J. R., Callahan R. C., et al. (2007). Teaching strategies. A guide to effective instruction. Boston: Houghton Miffling Company.

Piawa, C. Y. (2010). Building a test to assess creative and critical thinking simultaneously. Procedia - Social and Behavioral Sciences, 2(2), 551-559. https://doi.org/10.1016/j.sbspro.2010.03.062

Renstein, A. \& Lander, G. H. (1990). Developing critical thinking in college programs. Journal of Scientific. Exploration, vol. 4, No. 2. 123-136.

Ruseffendi, E.T. 1988. Pengantar kepada Membantu Guru Mengembangkan Kompetensinya dalam Pengajaran Matematika untuk Meningkatkan CBSA. Bandung: Tarsito.

Sanjaya, Wina. (2011). Strategi Pembelajaran Berorientasi Standar Proses Pendidikan. Jakarta:Prenada Media.

Saputra, M. D., Joyoatmojo, S., Wardani, D. K., \& Sangka, K. B. (2019). Developing Critical-Thinking Skills through the Collaboration of Jigsaw Model with ProblemBased Learning Model. International Journal of Instruction, 12(1), 1077-1094. https://doi.org/10.29333/iji.2019.12169a

Setiawan. (2012). Meningkatkan Kemampuan Koneksi dan Pemecahan Masalah Matematik Siswa melalui Pembelajaran Kooperatif Model Cooperative Integrated Reading and Composition (CIRC). Tesis SPS UPI: Tidak diterbitkan.Bandung. 
Sundari, P. D., Parno, \& Kusairi, S. (2016). Hubungan Antara Efikasi-Diri Dan Kemampuan Berpikir Kritis Siswa. Makalah dipresentasikan pada Seminar Nasional Pendidikan IPA Pascasarjana UM. Malang. Retrived from https://www.researchgate.net/publication/330314939_STUDENTS'_CRITICAL_TH INKING_ABILITY_IN_INTEGRATED_LEARNING_MODEL

Suparman, Atwi. 2012. Desain Instruksional Modern: Panduan Para Pengajar dan Inovator Pendidikan. Erlangga. Jakarta. 